\title{
PHYSIOLOGICAL STATUS, BLOOD PROFILE AND BODY COMPOSITION OF SHEEP FED WITH CA-SAPONIFIED LEMURU OIL COATED BY HERBS
}

\section{STATUS FISIOLOGI, PROFIL DARAH DAN KOMPOSISI TUBUH DOMBA YANG DIBERI MINYAK LEMURU TERSAPONIFIKASI DAN DISALUT DENGAN HERBAL}

\author{
Dewi Apri Astuti* and Asep Sudarman \\ Department of Nutrition and Feed Technology, Faculty of Animal Science, Bogor Agricultural University,
} Bogor, 16680

Submitted: 5 February 2015, Accepted: 18 March 2015

\begin{abstract}
This study was aimed to evaluate the physiological status, blood profiles and body composition of sheep fed with Ca-saponified lemuru oil coated by herbs. Twenty fat-tailed sheep (av. BW $23 \pm 1.2 \mathrm{~kg}$ ) were used in this experiment by using Completely Randomized Design with five treatments ration and four replications of each. Sheep fed with concentrate containing 3\% Ca-saponified lemuru oil and king grass (1:1) ad libitum. Treatments were control diet without herbs (R1); Ca-saponified lemuru oil coated by curcumae domestica (R2); coated by Zingiber officinale Rosc (R3); coated by Eugenia polyantha (R4) and coated by Pluchea indica Less (R5). Data of physiological parameters were measured three times a day, in the morning, at noon and afternoon. Blood samples were collected at the end of the experiment through jugular vein, together with zero sample for Urea Space measurement. The variables observed were physiological data (heart rate, respiration rate, and rectal temperature), blood profiles (erythrocyte, hemoglobin, packed cell volume (PCV), leucocytes) and body composition (water, protein and fat) measured using Urea Space technique. Results of the study showed that sheep fed with Ca-saponified lemuru oil coated by herbs was not significantly different on heart rate, respiration rate and rectal temperature among treatments. Meanwhile, total leucocytes, neutrophil cell, and lymphocytes significantly increased $(P<0.05)$ by the treatment. Body composition percentage (water, protein and fat) were same in all treatments, except the total body fat and energy retained. In conclusion, supplementation of $3 \%$ Casaponified lemuru oil coated by Curcumae domestica, Zingiber officinale Rosc, Eugenia polyantha and Pluchea indica Less in fat-tailed sheep had no effect on physiological parameters, but improved the leucocyte and neutrophil cells. Total body fat and energy retained lower compared to control treatment.
\end{abstract}

(Key words: Body composition, Ca-saponified, Herbs, Lemuru oil, Urea space)

\section{INTISARI}

Penelitian ini bertujuan untuk mengevaluasi parameter fisiologis, profil darah dan komposisi tubuh domba ekor gemuk yang diberi pakan sabun kalsium yang disaponifikasi dengan minyak lemuru dan disalut berbagai jenis herbal. Sebanyak 20 ekor domba ekor gemuk (BB 23 $1,2 \mathrm{~kg}$ ) digunakan pada penelitian ini dalam suatu rancangan acak lengkap dengan 5 perlakuan dan 4 ulangan. Domba diberi pakan konsentrat yang mengandung 3\% sabun kalsium yang disaponifikasi dengan minyak lemuru dan disalut herbal dan rumput gajah (1:1) dan air minum secara ad libitum. Perlakuan control tanpa sabun kalsium (R1), konsentrat mengandung $3 \%$ sabun kalsium yang disaponifikasi dengan minyak lemuru dan disalut herbal kunyit (R2), jahe (R3), daun salam (R4) dan daun bluntas (R5). Data nadi jantung, respirasi dan suhu tubuh diukur tiga kali sehari, pagi, siang dan sore. Sampel darah diambil pada akhir penelitian bersamaan dengan pengukuran zero sample untuk pengukuran ruang urea. Variabel yang diukur meliputi status fisiologi, gambaran darah, dan komposisi tubuh yang diukur dengan menggunakan metode ruang urea. Hasil penelitian menunjukkan bahwa tidak ada perbedaan status fisiologi antar perlakuan, tetapi ada peningkatan total lekosit, netrofil, dan limfosit pada perlakuan penambahan sabun kalsium yang disalut herbal $(P<0,05)$. Tidak ada perbedaaan yang nyata pada komposisi tubuh akibat perlakuan, kecuali pada total retensi lemak tubuh dan energi yang lebih rendah pada perlakuan penambahan sabun kalsium yang disalut herbal. Kesimpulan dari penelitian ini bahwa penambahan 3\% sabun kalsium disaponifikasi dengan minyak lemuru yang disalut herbal kunyit, jahe, daun salam dan daun bluntas tidak mengakibatkan perubahan status fisiologi tetapi dapat meningkatkan status imun melalui peningkatan lekosit dan deferensiasinya serta menurunkan total retensi lemak tubuh dan energi domba ekor gemuk.

(Kata kunci: Herbal, Komposisi tubuh, Minyak lemuru, Ruang Urea, Sabun kalsium)

\footnotetext{
* Korespondensi (corresponding author):

Telp. +62 8129428 546, E-mail: dewiapriastuti86@gmail.com
} 


\section{Introduction}

Sheep and goat are small ruminants that reared as dual purpose. Specific problem in tropical countries is high humidity and environmental temperature that can decrease feed intake to anticipate heat accumulation during daytime feeding, difficulties to evaporate heat production and increase respiration rate. On the other hand, high forages intake caused high heat increment (Astuti and Sastradipradja, 2000; Sudarman and Ito, 2000). This condition will directly improve the physiological status, immune respond, and production. To overcome the situation, it is needed to formulate a ration which high energy content but resulted in low heat increment. Fat has higher energy content compared to carbohydrate and protein. As a feedstuff, fat results low in heat increment during metabolism process, so it is appropriate to supplement the animal ration in the tropical country to reduce heat stress. The good quality source of polyunsaturated fatty acid (PUFA) which high omega-3 content are lemuru oil from the lemuru fish. Sudarman et al. (2006) reported that utilization of $1.5 \% \mathrm{Ca}$ saponified lemuru oil in ration could increase feed efficiency by $36 \%$ and reduce meat cholesterol-LDL on sheep by $32 \%$. Meanwhile, Wachira et al. (2002) reported that fish oil could reduce dry matter intake in sheep. To reduce negative effect of fat supplementation in the rumen fermentation, it should be introduced a feed technology to manipulate rumen system by using saponification with calcium, with the consequence the ration will have bad smell and caused low palatability. In order to increase palatability of ration containing lemuru oil with Ca-saponified, so the lemuru oil with Ca-saponified should be coated with those herbs.

Herbs have been used for many purposes on the animal farming system and had a good effect on palatability. Curcumae domestica, Zingiber officinale Rosc., Eugenia polyantha and Pluchea indica are some herbs that have specific smelt and good taste. The secondary compound of Eugenia polyantha is eugenol, citral, and methyl chavicol, while secondary compound of Zingiber officinale is fellandren, kamfer, borneol, zingiberin, zingiberol, gigerol, zingeron, vitamin A, B1, C and the secondary compound of Curcumae domestica is turmeron, zingiberen, turmerol, fellandren (Asiamaya, 2006). The secondary compound of Pluchea indica is some amino acids such as leusin, isoleucine, tryptophan, threonine, vitamin A and C (Asiamaya, 2003). Percentage of herbs on lemuru oil should be determined for reducing side effect of the herbs.

Respiration rate, heart rate and rectal temperature of the animal depend on age, sex, physiological status, activity and environment, including climate and feeding. Ration containing high fat for animal reared in the tropical country may affect the physiological parameters. Meanwhile, Mc Manus et al. (2009) reported that there were significant differences in heart rate (94 versus $100 \mathrm{pulses} / \mathrm{min}$ ) and respiration rate (34 versus 39 times $/ \mathrm{min}$ ), between white coated sheep and black coated sheep, respectively, and the white showed lower than black. The experiment also reported that heart rate and respiration rate in the morning (92 pulses/min and 35 times $/ \mathrm{min}$ ) were lower than that in the afternoon (104 pulses/min and 49 times/min), respectively.

Fat supplementation in the ration will have an effect on body composition and meat quality. Substitution polysaturated fatty acid with polyunsaturated fatty acid could reduce total cholesterol, include LDL-cholesterol in the meat (Marsic and Yodice, 1992). It was also reported that PUFA omega-3 in the fish oil could reduce the risk of atherosclerosis (Iger, 2003). Meat cholesterol in sheep (80 $\mathrm{mg} \%)$ was higher than in beef $(74 \mathrm{mg} \%)$ and chicken broiler (73 mg\%) (Wachira et al., 2002). Meanwhile, Astuti and Sastradipradja (1999) reported that total body fat and body protein of growing priangan sheep fed concentrate and grazing on the pasture during half day and measured by Urea Space technique, were around $9.78 \%$ and $16.87 \%$, respectively.

Blood profiles have also affected by the composition of nutrient in the ration. It is very few information, according to the utilization of PUFA from lemuru oil coated by herbs in the sheep ration to evaluate the physiological status, blood profile, and body composition. This research was aimed to evaluate the effect of supplementation of different herbs (Curcumae domestica, Zingiber officinale, Eugenia polyantha and Pluchea indica Less) as coat of Ca-saponified lemuru oil in the ration, on physiological status, blood profile and body composition using urea space method in fat tail growing sheep. 


\section{Material and Methods}

This research was conducted at the Department of Animal Nutrition and Feed Technology, IPB during five months, including field experiment and data analysis. Twenty male fat-tailed growing sheep (av. $25 \pm 1,20$ $\mathrm{kgBW}$ ) were used in this experiment. Animal were fed concentrate contained Ca-saponified lemuru oil coated by Curcumae domestica, Zingiber officinale Eugenia polyantha and Pluchea indica Less of herbs and water served ad libitum in all time. The ration was consisted of concentrate and native grass 1 : 1. Concentrate $(87.5 \%$ DM) supplemented with $3 \%$ of Ca-saponified lemuru oil coated by the herb. Ca-saponified lemuru oil was made by double decomposition method (Jenkin and Palmquist, 1984). Before the ingredient mix with other feedstuffs, the herbs were added to $10 \%$ into Ca-saponified lemuru to coat the fat in order to reduce the strong smell. The formulation ration consisted of palm kernel meal, coconut meal, cassava meal, wheat pollard, molasses, urea, soybean meal and trace minerals. The composition of ration by proximate analysis was $16 \%$ crude protein, $5 \%$ of extract ether, $10 \%$ crude fiber and totally has $70 \%$ TDN. Using a Completely Randomized Design, four treatments with five replications were arranged as:

$\begin{aligned} & \mathrm{R} 1= \text { control ration without lemuru oil } \\ & \mathrm{R} 2= \text { ration supplemented with } 3 \% \text { Ca- } \\ & \text { saponified lemuru oil coated by } \\ & \text { Curcumae } \\ & \mathrm{R} 3= \begin{array}{r}\text { ration supplemented with } 3 \% \text { Ca- } \\ \text { saponified lemuru oil coated by Zingiber }\end{array} \\ & \mathrm{R} 4=\begin{array}{l}\text { ration supplemented with } 3 \% \text { Ca- } \\ \text { saponified lemuru oil coated by Eugenia }\end{array} \\ & \mathrm{R} 5=\begin{array}{l}\text { ration supplemented with } 3 \% \text { Ca- } \\ \text { saponified lemuru oil coated by Pluchea }\end{array}\end{aligned}$

During two months of the experiment the physiology parameters such as daily heart rate, respiration rate, and rectal temperature were measured in the morning at $08.00 \mathrm{am}$, at noon $12.30 \mathrm{pm}$ and afternoon at $16.00 \mathrm{pm}$. The heart rate was detected by using a stethoscope, rectal temperature was measured by using the thermometer inserted to the rectal for 5 minutes, and respiration rates was detected from expiration air through the mouth or nose.

At the end of the experiment period, blood sample of each sheep was collected for analysis of blood profiles such as erythrocyte, hemoglobin, PCV, leucocytes and its differentiation. After blood sampling for the hematology parameters, each sheep was injected with $0.65 \mathrm{mg} \%$ per $\mathrm{kg}$ metabolic body size (MBS) (around $130 \mathrm{mg}$ urea dissolved in 200g. $\mathrm{L}^{-1}$ sterile saline), through jugular vein within one minute, and time was recorded at the beginning and the end of injection. The jugular vein was flush with $3 \mathrm{ml}$ of heparinized saline after urea injection. Blood samples were obtained before urea injection and 12 minutes after the mean injection time. The actual quantity of urea injected was determined gravimetrically by weighing syringes before and after injection. The zero time blood samples were used to analyze hematology parameters while the rest were separated by centrifugation of blood at 10.000 $\mathrm{x} \mathrm{g}$ for 10 minutes to get plasma for urea-N analysis by KIT-BUN (merk Dya-Sis) method. The hematology parameters such as hemoglobin, PCV, erythrocyte, leukocytes, and lymphocytes were measured as standard procedures according to Sastradipradja et al. (1989). Urea space was calculated by dividing the dose of urea $\mathrm{N}$ injected with the change in plasma urea-N before and after 12 minutes injection, according to the equation as described by Bartle et al. (1983), while body protein and fat were calculated following Panaretto and Till (1963), and body water according to Rule et al. (1986). All formulas were expressed based on live weight (\%LW) as followed:

$$
\begin{aligned}
& \text { Urea } \\
& \begin{array}{l}
\text { Space } \\
(\text { US,\%) }
\end{array}=\frac{\text { Dose of urea-Ninjected }(\mathrm{mg})}{\text { Change in plasma urea-N }(\mathrm{mg} \%)} \\
& \quad \text { X } 10 \times \text { Live Weight }(\mathrm{LW}, \mathrm{kg})
\end{aligned}
$$

Body water $(\mathrm{BW}, \%)=59.1+0.22 \times$ US $(\%)-$ 0.04 LW $(\mathrm{kg})$

Body protein $(\mathrm{BP}, \mathrm{kg})=0.265 \times \mathrm{BW}$ (Liter) 0.47

Body fat $(\mathrm{BF}, \%)=98.0-1.32 \times \mathrm{BW}(\%)$.

Data of total body fat and body protein were calculated from body weight gain times percent body fat dan protein, while total energy retention was calculated using the heat of combustion values of protein (23.85 $\mathrm{kj} / \mathrm{g})$ and fat $(38.50 \mathrm{kj} / \mathrm{g})$ times total body fat and protein (Astuti and Sastradipradja, 1999). The significance of the difference between means was compared by using Duncan Multiple Range Test after ANOVA with program Minitab/SPSS release 6.1 version. 


\section{Results and Discussion}

\section{Physiological status}

The data on physiological status are presented in Table 1. There were no significant differences in heart rate, rectal temperature and respiration rate among treatments. The average data on rectal temperature, respiration and heart rate range from $38-39^{\circ} \mathrm{C}, 29-60 \mathrm{times} / \mathrm{min}$ and $90-113$ pulse/min, respectively. There were the tendency of increasing respiration (two times) and heart rate $(10 \%)$, especially at noon and afternoon during exposed at room temperature $28-33^{\circ} \mathrm{C}$. The increasing respiration and heart rate were correlated with daily activities due to heat stress, environmental temperature and humidity (upper than $78 \%$ relative). This data were similar to that reported previously where the respiration was around 50 times/min and the heart rate was more than $90 \mathrm{pulse} / \mathrm{min}$ in the afternoon (Astuti et al., 2009). Heat stress is considered a limiting factor for animal production. Well adapted animals are characterized by maintenance or minimum production loss during the stress period, high reproductive efficiency, high disease resistance, longevity and low mortality rate. When an animal starts to suffer due to heat, feed ingestion is reduced and metabolism slows, causing a hypo function of the thyroid. This affects growth, reproduction efficiency, feed conversion, milk production, and economic losses (Marai et al., 2007). Mean while, Abdoun et al. (2013) reported that supplementation of $3-5 \%$ seaweed as a herb on ration has no effect on rectal and skin temperature, but could significantly reduce respiration rate of lambs.

\section{Blood profiles}

Blood

hemoglobin, and PCV) were same in all treatments and in the range of normal condition. The normal value of erythrocyte, hemoglobin, and PCV of growing sheep is 6$9 \times 10^{6} / \mathrm{mm}^{3}, \quad 10-12 \mathrm{~g} \%$, and $28-32 \%$, respectively (Adriana et al., 2010). Total erythrocyte will decrease following the age. Data on erythrocyte and hemoglobin in this experiment were higher than those data reported previously of the local sheep reared under the tropical rain forest area with low quality of ration, with the number of erythrocytes was $7.57 \times 10^{6} / \mathrm{mm}^{3}$, hemoglobin was $7.21 \mathrm{mg} \%$ and PCV was $28.10 \%$ (Astuti et al., 2009). Leucocytes, lymphocytes, and neutrophils cells were significantly higher in the treatment groups $(P<0.05)$ compared to control. Herbs have secondary compound that can improve body immune system in such of proper dose. Ca-saponified lemuru oil coated by $10 \%$ of Curcumae, Zingiber, Eugenia and Pluchea have increased the number of leucocytes and neutrophil due to the presence of specific secondary compound. Mc Manus et al. (2009) reported that there were no significance differences between sheep breeds (white, black and brown coated) fed with different ration, in the blood profiles. Hematocryte, total plasma protein erythrocyte, hemoglobin, leucocytes, MCV, and $\mathrm{MCHC}$ were same in all breeds and rations. Meanwhile, Norouzian et al. (2010) reported that the hematological profile of lambs fed clinoptilolite have $31 \%$ of hematocrit, $10.5 \mathrm{mg} \%$ of hemoglobin, $10.83 \times\left(10^{6} / \mathrm{mm}^{3}\right) \quad$ erythrocyte $7.62 \times\left(10^{3} / \mathrm{mm}^{3}\right)$ leucocytes, $50 \%$ neutrophils and $45 \%$ of lymphocyte. It is well known that

Table 1. Physiological status of sheep fed with Ca-saponified lemuru oil coated by herbs

\begin{tabular}{lccccc}
\hline \hline \multicolumn{1}{c}{ Variable } & R1 & R2 & R3 & R4 & R5 \\
\hline Body temperature $\left({ }^{\circ} \mathrm{C}\right):$ & 38.70 & 38.70 & 38.40 & 38.50 & 38.60 \\
$\quad$ Morning & 38.90 & 38.80 & 38.80 & 38.70 & 38.90 \\
$\quad$ Noon & 39.10 & 39.00 & 39.00 & 39.00 & 39.00 \\
$\quad$ Afternoon & & & & & \\
Heart rate (beat/min): & 97 & 94 & 90 & 97 & 96 \\
$\quad$ Morning & 102 & 100 & 91 & 98 & 103 \\
$\quad$ Noon & 115 & 105 & 100 & 113 & 31 \\
$\quad$ Afternoon & & & & 30 & 58 \\
Respiration: /min & 29 & 30 & 32 & 60 & 48 \\
$\quad$ Morning & 49 & 63 & 61 & 43 & \\
$\quad$ Noon & 52 & 53 & 54 &
\end{tabular}


leucocyte and neutrophyl is part of immune system on the body (Bratawidjaja, 2006). Growing sheep fed with tropical browse plants such glirisidae, moringa and arthocarpus that has specific secondary compounds resulted in higher IgG and number of leucocytes (Astuti et al., 2011). Hosoda et al. (2006) reported that there was the effect of three herbs as feed supplements on blood metabolites, hormones, antioxidant activity, IgG concentration, and rumen fermentation in Holstein steers. It has also reported that there was no significant difference in hematological parameters of ram fed moringa and saman leaves (Maherniyanto et al., 2013).

\section{Body compositions}

There were no significant differences in body compositions (water, fat, and protein) among treatments by using urea space technique. Body water was around $57 \%$; body fat was $21.8 \%$ and body protein was $14.9 \%$. The lower body water in these growing sheep than that, in general, was due to the high fat percentage. The fat percentage will increase following the age while body water and protein will decrease in the older animal. Statistically, the total fat in Ca-saponified lemuru oil coated by $10 \%$ of Curcumae, Zingiber, Eugenia and Pluchea treatments were lower than control ration $(P<0.05)$. This condition caused the lower energy retained in herbs groups. Energy retained $(\mathrm{kJ})$ in herb treatments were lower than those of control $(P<0.05)$. Secondary compounds and high fiber content in herbs will improve the fat deposition. Astuti et al. (2009) reported that Sapindus rarak with secondary compound tanin in $\mathrm{PO}$ cattle ration could reduce total cholesterol and body fat. It was similar also with previous data of Curcumae treatment that could reduce fat-cholesterol (Sudarman et al., 2006). Fatty acid composition and cholesterol content of beef and chicken meat in Southern Brazil have close related with the type of ration as reported by Carnevale et al. (2006).

The percentage of body water and body protein in this study were lower than those reported previously in growing priangan sheep fed with concentrate evaluated by slaughter technique (\% empty body weight), where the body water and body protein of growing Priangan sheep were around $65.87 \%$ and $16.53 \%$, while body fat was $9.85 \%$ (Astuti and Sastradipradja, 1999). There is close correlation between age, sex, ration and physiological status of the animal to the body composition and also with carcass composition (Rule et al., 1986). Fish oil in the diet reduced dry matter intake and lamb live weight gain while the muscle proportion was increased. The proportions of the longer-chain $\mathrm{n}-3$ polyunsaturated fatty acids were similar in Suffolk, Soay and Friesland breed with different kind of fat sources (Wachira et al., 2002).

Table 2. Blood profile of sheep fed with Ca-saponified lemuru oil coated by herb

\begin{tabular}{|c|c|c|c|c|c|}
\hline Variable & R1 & R2 & R3 & R4 & R5 \\
\hline $\begin{array}{l}\text { Erythrocyte (10 } \\
6 / \mathrm{mm} 3)\end{array}$ & $10.60 \pm 1.01$ & $10.40 \pm 0.70$ & $10.70 \pm 0.99$ & $9.10 \pm 1.10$ & $9.70 \pm 0.37$ \\
\hline Hemoglobin ( $\mathrm{g} \%)$ & $9.10 \pm 0.70$ & $8.67 \pm 0.58$ & $8.70 \pm 0.51$ & $8.50 \pm 0.40$ & $7.00 \pm 0.90$ \\
\hline PCV (\%) & $26.00 \pm 2.00$ & $29.00 \pm 4.00$ & $29.00 \pm 2.60$ & $28.50 \pm 2.50$ & $28.00 \pm 1.50$ \\
\hline Leucocyte $\left(10^{3} / \mathrm{mm} 3\right)$ & $8.00 \pm 0.30^{b}$ & $9.50 \pm 0.09^{a}$ & $8.40 \pm 0.01^{\mathrm{ab}}$ & $8.90 \pm 0.30$ & $7.90 \pm 0.22^{a}$ \\
\hline Lymphocyte (\%) & $41.75 \pm 15.00^{b}$ & $52.75 \pm 13.00^{a}$ & $37.00 \pm 11.00^{b}$ & $39.50 \pm 7.00^{b}$ & $35.25 \pm 5.00^{\mathrm{b}}$ \\
\hline Neutrophil (\%) & $45.00 \pm 15.00^{b}$ & $49.50 \pm 9.70^{\mathrm{a}}$ & $56.00 \pm 11.50^{a}$ & $50.00 \pm 5.85^{a}$ & $53.00 \pm 5.00^{\mathrm{a}}$ \\
\hline
\end{tabular}

Table 3. Body composition of sheep fed with Ca-saponified lemuru oil coated by herbs

\begin{tabular}{lccccc}
\hline \hline \multicolumn{1}{c}{ Variable } & R1 & R2 & R3 & R4 & R5 \\
\hline Body water (\%) & 57.70 & 57.80 & 57.80 & 57.90 & 57.80 \\
Body fat (\%) & 21.80 & 21.70 & 21.70 & 21.60 & 21.70 \\
Body protein (\%) & 14.80 & 14.80 & 14.90 & 14.90 & 14.90 \\
Total fat (kg) & $7.62^{\mathrm{a}}$ & $7.34^{\mathrm{b}}$ & $7.35^{\mathrm{b}}$ & $6.90^{\mathrm{b}}$ & $7.32^{\mathrm{b}}$ \\
Total protein (kg) & 5.18 & 5.03 & 5.03 & 4.76 & 5.01 \\
Total body energy (kJ/head) & $424.21^{\mathrm{a}}$ & $410.04^{\mathrm{b}}$ & $409.83^{\mathrm{b}}$ & $385.68^{\mathrm{b}}$ & $408.44^{\mathrm{b}}$ \\
\hline
\end{tabular}

R1= control, R2, R3, R4, and R5 were Ca-saponified lemuru oil coated by $10 \%$ of curcumae, ginger, Eugenia and Pluchea, respectively.

$a, b$ Superscript with a different notation in the same column was significantly different $(P<0.05)$. 


\section{Conclusion}

Supplementation of 3\% Ca-saponified lemuru oil coated by herb (Curcumae, Zingiber, Eugeniapolyantha and Pluchea indica) in concentrate for fat-tailed sheep have no effect on physiological status meanwhile had better immune response (higher leucocytes, lymphocytes and neutrophils) and lower total body fat and energy retained.

\section{Acknowledgement}

I would like to thank to the team of this research project and supported grant from Hibah Bersaing 2005, Directorate General of Higher Education, Ministry of Education and Cultural RI.

\section{References}

Abdoun, K. A, A. B. Okab, A. M. El-Waziry, E. M. Samara and A. A. Al-Haidary. 2013. Dietary supplementation of seaweed (Ulva lactuca) to alleviate the impact of heat stress in growing lambs. Pak. Vet. J. 34: 108-111.

Adriana, Suharsono and Elfira. 2010. Fisiologi Ternak. UNPAD Press, Bandung.

Astuti, D. A., A. S. Baba and I. W. T. Wibawan. 2011. Rumen fermentation, blood metabolite and performance of sheep fed with tropical browse plants. J. Med. Pet. 34: 201-206.

Astuti, D. A., E. Wina, B. Haryanto, dan S. Suharti. 2009. Performa dan profil beberapa komponen darah sapi Peranakan Ongole yang diberi pakan yang mengandung lerak (Sapindus rarak De Candole). J. Med. Pet. 32: 6370.

Astuti, D. A., R. E. Kastuti, Marwah and Yani. 2009. Status nutrien dan gambaran darah domba lokal yang dipelihara di hutan pendidikan Gunung Walat, Sukabumi. Jurnal Pertanian UNSYAH 1: $1-8$.

Astuti, D. A. and Sastradipradja. 2000. Energy metabolism in relation to grazing activity in growing priangan sheep as affected by rations. Indon. J. Tropical Agric. 9: 1-6.

Astuti, D. A. and Sastradipradja. 1999. Evaluation of body composition using urea dilution and slaughter technique of growing priangan sheep. J. Media Veteriner 6: 5-11.
Asiamaya. 2003. Beluntas. http://www.asia maya.com/jamu/isi/beluntas_plucheain dicaLess.Htm. Accessed 12 Maret 2006.

Asiamaya. 2006. Jahe. http://www.asia maya.com/jamu/isi/jahezingiberofficina le.htm. Accessed 20 Mei 2006.

Bartle, S. J., J. R. Males and R. L. Preston. 1983. Evaluation of urea dilution as an estimator of body composition in matur cows. J. Anim. Sci. 56: 410-417.

Bratawidjaja, K. G. 2006. Imunologi Dasar. Edisi ke 3. Fakultas Kedokteran, Universitas Indonesia Jakarta.

Carnevale de Almeida, J., M. S. Perassolo, J. L. Camargo, N. Bragagnolo and J. L. Gross. 2006. Fatty acid composition and cholesterol content of beef and chicken meat in Southern Brazil. Revista Brasileira de Ciências Farmacêuticas. Brazilian J. Pharmaceutical Sci. 42: 109-117.

Hosoda, K., K. Kuramoto, B. Eruden, T. Nishida and S. Shioya. 2006. The effect of three herbs as feed supplements on blood metabolites, hormones, antioxidant activity, IgG concentration, and ruminal fermentation in holstein steers. Asian-Aust. J. Anim. Sci. 19: 3541.

Iger. 2003. Healthy Beef. http://www.seed sohealth.co.uk/articles/healthy_beef.sh tml. Accessed 20 May 2006.

Jenkin, T. C. and D. L. Palmquist. 1984. Effect of fatty acidor calcium soap on rumen and total nutrient digestibility of dairy ration. J. Dairy Sci. 67: 978-986.

Marheniyanto, E., H. Soetanto, Kusmartono and Hartutik. 2013. Blood profile and daily gain of fat-tailed growing rams receiving tree foliages to substitute other ingredients in the concentrate diets. OISR-JAVS 3: 23-27.

Marai, I. F. M, A. A. El Darawany, A. Fadiel and M. A. M. Abdel Hafez. 2007. Physiological traits as affected by heat stress in sheep, a Review. Small Rum. Res. 71: 1-12.

Marsic, V. and R. Yodice. 1992. The Dietary Role of Monounsaturates. INFORM, 3:681.

Mc Manus, C., G. R. Pakedo, H. Louvandini, R. Gugel, L. C. Sasaki and S. R. Paiva. 2009. Heat tolerance in Brazilian sheep; physiological and blood parameters. Trop. Anim. Health Prod. 41: 95-101. 
Norouzian, M. A., R. Valizadeh, A. A. Khadem, A. Afzalzadeh and A. Nabipour. 2010. The effects of feeding clinoptilolite on hematology, performance and health of newborn lambs. Biol. Trace Element Res. 137: 168-176.

Panaretto, B. A. and A. R. Till. 1963. Body composition in vivo. Aust. J. Agric. Res. 14: 926-943.

Rule, D. C., R. N. Arnold, E. J. Hentges and D. C. Betiz. 1986. Evaluation of urea dilution as a technique for estimating body composition of beef steers in vivo: validation of published equations and comparison with chemical composition. J. Anim. Sci. 63: 1935-1948.

Sastradipradja. D., S. H. S. Sikar, R. Widjajakusuma, T. Ungeru, A. Maad, $H$. Nasution, R. Suriawinata, dan R. Hamzah. 1989. Penuntun Praktikum Fisiologi Veteriner. Departemen Pendidikan dan Kebudayaan Direktorat Jenderal Pendidikan Tinggi Pusat Antar Universitas IImu Hayat, Institut Pertanian Bogor, Bogor.
Sudarman, A., K. G. Wiryawan, H. Nuraeni, M. Muttakin, dan H. Markhamah. 2006. Pengaruh pemberian sabun kalsium dari minyak ikan lemuru terhadap kinerja dan kualitas daging domba jantan lokal. Seminar Nutrisi dan Teknologi Pakan. Departemen IImu Nutrisi dan Teknologi Pakan, FAPETIPB, Bogor.

Sudarman, A. and T. Ito. 2000. Heat production and thermoregulatory responses of sheep fed different roughage proportion diets and intake levels when exposed to a high ambient temperature. Asian-Aust. J. Anim. Sci. 13: 625-629.

Wachira, A. M., L. A. Sinclair, R. G. Wilkinson, M. Enser, J. D. Wood and A. V. Fisher. 2002. Effects of dietary fat source and breed on the carcass composition, n-3 polyunsaturated fatty acid and conjugated linoleic acid content of sheep meat and adipose tissue. Br. J. Nutr. 88: 697-709. 